\title{
Drying of acerola residues in a roto-aerated dryer assisted by infrared heating
}

\author{
Silva, P. B. ${ }^{a^{*}}$; Nogueira, G. D. R. ${ }^{\text {a }}$ Duarte, C. R. ${ }^{\text {a }}$; Barrozo, M. A. S. ${ }^{a^{*}}$ \\ ${ }^{a}$ Chemical Engineering School. Federal University of Uberlândia, Uberlândia, MG, Brazil, \\ *E-mail of the corresponding author: masbarrozo@ufu.br; priscilabernardeseq@gmail.com
}

\begin{abstract}
Acerola (Malpighia emarginata D.C.) is a tropical fruit which has attracted recent industrial interest, due to its high levels of bioactive compounds and vitamin C. However, acerola processing generates a substantial amount of wastes, which can represent up to $40 \%$ of total processed volume. The drying of acerola residues in a new dryer, developed by our research group, named as roto-aerated dryer, has been investigated. This dryer provides a better fluid-particle contact than the conventional rotatory dryer. A pre-drying system with infrared lamps has been installed in the feed of this new dryer. The effect of the pre-treatment of this fruit residues with ethanol was also investigated. The results shown that the roto-aerated dryer assisted by infrared radiation hybrid combined with a pre-treatment with ethanol is a good alternative for processing fruit residues, aiming their reuse. It was possible to identify conditions under which the phenolic, flavonoid, and antioxidant capacity presented high levels after drying. The main phenolic compounds were idenfied by HPLC.
\end{abstract}

Keywords: Drying; roto-aerated dryer; infrared; acerola 


\section{Introduction}

Byproducts of fruit processing industries, such as seeds, kernels and bagasse, which were previously considered wastes, have high potential to be used as food supplement. This aspect, along with the increasing global interest in environmental friendly technologies, explains the interest in a better utilization of fruit processing industries residues ${ }^{[1]}$.

Acerola (Malpighia emarginata D.C.) is a tropical fruit originates from tropical America. Its pleasant flavor and the high levels of vitamin $\mathrm{C}$ have led to its increasing use in the form of juice, jelly and compote. The residues of acerola processing can contain higher amounts of phenolic and other bioactive compounds than the edible fleshy parts. ${ }^{[1]}$

A challenge faced by drying of this fruit residues is to reduce the exposure time at elevated temperatures, which may cause deterioration of the bioactive compounds present in the material ${ }^{[2]}$. Rotary dryers are interesting alternatives for drying of fruit residues, because of their flexibility in handling a wider range of materials than other types of dryers. Several studies in the literature ${ }^{[3]}$ have focused on developing modifications on rotary dryers to improve their performance. Thus, another version of the rotary dryer, named as roto-aerated dryer, was designed by our research group. The main characteristic of this nonconventional rotary dryer is the effective contact time between hot air and wet solids and consequently the drying efficacy ${ }^{[3]}$.

In this work, a pre-drying system with infrared lamps has been installed in the infeed conveyor of this new dryer. The effect of a pre-treatment of the acerola residues with ethanol was also analyzed. The drying performance of this novel system was investigated. The quality parameters, such as phenolics and flavonoids contents were also studied.

\section{Materials and Methods}

\subsection{Material}

The acerola wastes used in this work came from industrial juice processing (Fruteza Company, from Sao Paulo-Brazil). The material was stored in frozen at approximately $18^{\circ} \mathrm{C}$. The Samples were removed from the freezer 12 hours prior to the drying and then placed in the refrigerator at $5^{\circ} \mathrm{C}$ to thaw.

\subsection{Experimental apparatus and conditions}

Figure 1 shows a schematic diagram of the experimental apparatus which consist of a 7.5HP blower coupled to a duct; an air heating system comprised of electric resistances controlled by a variac and the roto-aerated dryer. The solids feed was performed through a conveyor belt (3) mounted below a reservoir (4), where the wet particulate material was stored. The material was conveyed to another conveyor (5) in order to more effectively adjust the feed rate. On the second conveyor belt was mounted a pre-drying system with 
four infrared lamps (6). The power of the lamps was adjusted by a Variac transformer ( 0 to $1200 \mathrm{~W})$. The drum (7) inclination angle was $3^{\circ}$, and the rotation speed was $2.7 \mathrm{rpm}$. The drum used in this study was $1.5 \mathrm{~m}$ long and $0.29 \mathrm{~m}$ wide. The configuration of the rotoaerated dryer had 56 mini-pipes (8): 10 mini-pipes near the solids feed, with $0.004 \mathrm{~m}$ diameter; 12 mini-pipes in the middle with $0.006 \mathrm{~m}$ diameter, and 34 mini-pipes near the solids discharge with $0.009 \mathrm{~m}$ diameter. The mini-pipes had a length of $0.095 \mathrm{~m}$ and they were placed at $0.02 \mathrm{~m}$ from the particle bed. The solids flow rate was of $0.045 \mathrm{~kg} \mathrm{~min}^{-1}$. The temperatures of the air and solids were measured using copper-constantan thermocouples calibrated by means of a thermostatic bath and a mercury thermometer with a precision of $0.05{ }^{\circ} \mathrm{C}$. The relative humidity ranged between 30 and $40 \%$. For the conditions used in the present work,the holdup ranged from $65.6 \mathrm{~g}$ to $194.2 \mathrm{~g}$. The residence time $(\tau)$ was determined by the ratio between hold up and the solids flow rate. The pre-treatment with ethanol have been performed spraying $93.2{ }^{\circ} \mathrm{GL}$ ethanol onto the residues, in the proportion of $2 \mathrm{~L}$ of alcohol to $3 \mathrm{~kg}$ of solids [4].

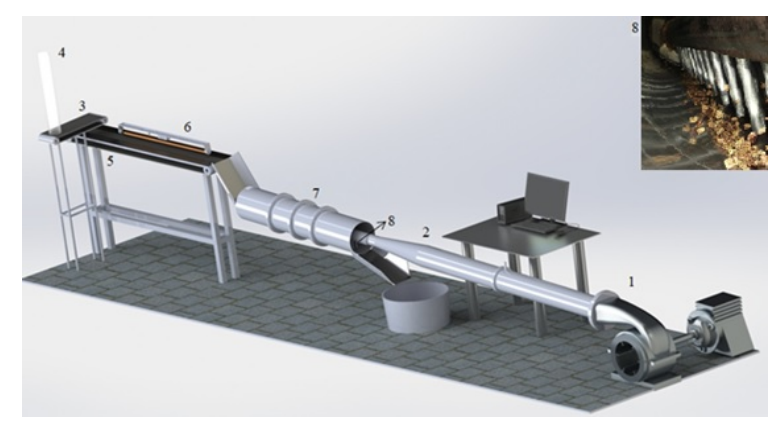

Fig. 1 Experimental apparatus.

The experimental conditions were chosen considering a central composed design ${ }^{[3]}$ with 3 replicates at the center levels (Table 1). The independent variables analyzed were the air velocity $(v)$, air temperature $(T)$ and infrared lamp power $(P)$.

Table 1. Experimental design

\begin{tabular}{cccc|cccc}
\hline Exp. & $\mathrm{T}\left({ }^{\circ} \mathrm{C}\right)$ & $\mathrm{v}(\mathrm{m} / \mathrm{s})$ & $\mathrm{P}(\mathrm{W})$ & Exp. & $\mathrm{T}\left({ }^{\circ} \mathrm{C}\right)$ & $\mathrm{v}(\mathrm{m} / \mathrm{s})$ & $\mathrm{P}(\mathrm{W})$ \\
\hline 1 & 80.0 & 1.5 & 600.0 & 11 & 115.0 & 1.3 & 850.0 \\
2 & 80.0 & 1.5 & 1100.0 & 12 & 115.0 & 3.3 & 850.0 \\
3 & 80.0 & 3.0 & 600.0 & 13 & 115.0 & 2.3 & 511.7 \\
4 & 80.0 & 3.0 & 1100.0 & 14 & 115.0 & 2.3 & 1188.3 \\
5 & 150.0 & 1.5 & 600.0 & 15 & 115.0 & 2.3 & 850.0 \\
6 & 150.0 & 1.5 & 1100.0 & 16 & 115.0 & 2.3 & 850.0 \\
7 & 150.0 & 3.0 & 600.0 & 17 & 115.0 & 2.3 & 850.0 \\
9 & 150.0 & 3.0 & 1100.0 & 18 & 180.0 & 2.3 & 1188.3 \\
8 & 67.6 & 2.3 & 850.0 & $19^{*}$ & 180.0 & 2.3 & 1188.3 \\
10 & 162.4 & 2.3 & 850.0 & & & & \\
\hline
\end{tabular}

* With pre-treatment with ethanol 


\subsection{Quality parameters}

The moisture content was determined by the oven method at $105 \pm 3{ }^{\circ} \mathrm{C}$ for $24 \mathrm{~h}$. The Kjeldahl method was used to determine the protein content, while the crude lipid and total dietary fibers (TDF) were determined using the Soxhelt method and neutral detergent $20 \%$ method, respectively, according to AOAC methods ${ }^{[5]}$. The carbohydrate content was determined by the difference. Minerals were quantified by X-ray fluorescence (FRX) using a Shimadzu device (EDX-720). Total phenolics content (TPC) were determined by the Folin Ciocalteu method ${ }^{[6]}$, using gallic acid monohydrate (99\%). Total flavonoids content (TFC) were determined using the colorimetric method described by Zhishen et al. ${ }^{[7]}$. DPPH analyzes were performed according to Brand-Williams et al. ${ }^{[8]}$ to obtain the amount of antioxidant necessary to decrease the initial $\mathrm{DPPH} \bullet$ concentration by $50 \%\left(\mathrm{IC}_{50}\right)$. The phenolic acids was identified through HPLC according to Ribeiro et al. ${ }^{[9]}$. All analyses of antioxidant compounds were performed in triplicate and the results expressed in mean value \pm SD. The differences between means were analyzed by analysis of variances (ANOVA with $\mathrm{p}<0.05$ ).

\section{Results and Discussion}

The characterization of acerola residue showed that this material had a high concentration of total fibers $(51.12 \pm 0.52 \mathrm{~g} / 100 \mathrm{~g}$ d.w.). The Food Nutrition Board (FNB), through the Indicated Daily References (DRI), set the appropriate recommendation for $38 \mathrm{~g}$ fibers for men and $25 \mathrm{~g}$ for women, both adults. The amount of protein $(10.13 \pm 0.15 \mathrm{~g} / 100 \mathrm{~g} \mathrm{~d} . \mathrm{w}$.$) ,$ lipids (5.43 $\pm 0.37 \mathrm{~g} / 100 \mathrm{~g}$ d.w.) and carbohydrates $(30.86 \pm 0.12 \mathrm{~g} / 100 \mathrm{~g}$ d.w.) demonstrate the potential of this material to be used as a food supplement, aiming to add protein and energy values. The results of the X-ray fluorescence spectrometry (FRX) analysis showed the predominance of potassium (3650 mg/100g d.w.), calcium (805 $\mathrm{mg} / 100 \mathrm{~g} \mathrm{d.w}$ ) and phosphorus $(420 \mathrm{mg} / 100 \mathrm{~g} \mathrm{~d} . \mathrm{w}$.) in the acerola residue. Magnesium (130 $\mathrm{mg} / 100 \mathrm{~g} \mathrm{d.w.})$ and molybdenum $(30 \mathrm{mg} / 100 \mathrm{~g} \mathrm{d.w}$.) were also detected. These compounds participating in metabolic reactions and are also associated with prevention of cardiovascular disease, decreased osteoporosis, diabetes and Alzheimer's ${ }^{[1]}$.

Figure 2 show the results of drying of acerola residues in the roto-aerated dryer assisted by infrared radiation. The initial moisture content of the material was $78.7 \pm 0.8 \mathrm{~g} / 100 \mathrm{~g}$ w.b., and after the infrared radiation $\left(\mathrm{M}_{\text {infrared }}\right)$ reached until $59.1 \mathrm{~g} / 100 \mathrm{~g}$ w.b. (Experiment 14 (E14) $-1188 \mathrm{~W})$, a $24.3 \%$ of moisture reduction. The exposure time of the material to the infrared lamps was $9 \mathrm{~min}$. For the powers of 600,850 and $1100 \mathrm{~W}$ the average moisture reduction was $1.9 \pm 0.1 \%, 11.4 \pm 1.0 \%$ and $18.3 \pm 1.6 \%$, respectively. 


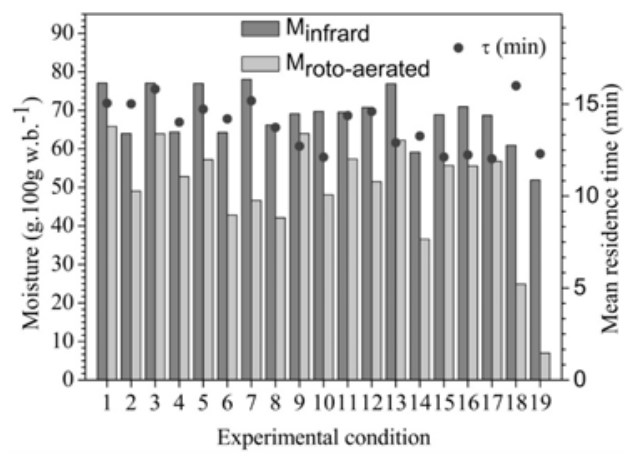

(a)

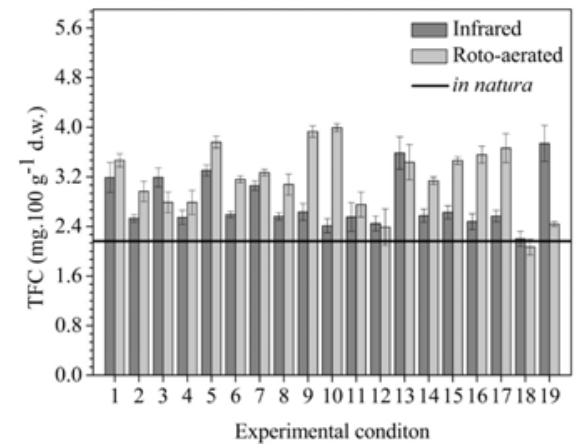

(c)

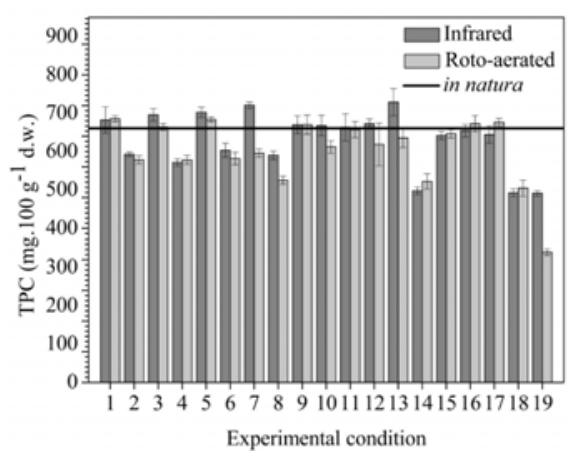

(b)

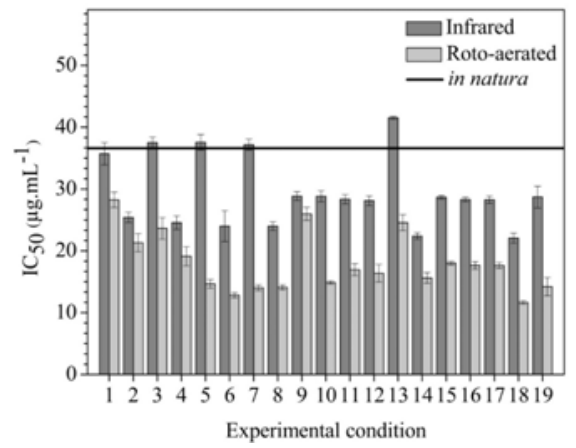

(d)

Fig. 2 Results of drying of the acerola residue after infrared and roto-aerated.

The moisture of the material fed to the roto-aerated dryer varied according to the power of the infrared pre-drying, which was $77.3 \pm 0.5(600 \mathrm{~W}), 69.7 \pm 0.9(850 \mathrm{~W})$ and $64.7 \pm 1.0$ $(1100 \mathrm{~W}) \mathrm{g} / 100 \mathrm{~g}$ w.b. The average residence time of the material in the dryer ranged from $3.0 \mathrm{~min}(\mathrm{E} 17)$ to $6.8 \mathrm{~min}(\mathrm{E} 3)$. The final moisture of the material after the roto-aerated dryer $\left(\mathrm{M}_{\text {roto }}\right)$ ranged from 65.8 to $36.6 \mathrm{~g} / 100 \mathrm{~g}$ w.b. for conditions $\mathrm{E} 1$ and E14, respectively. Therefore, it was possible to reduce the initial moisture content of the material by up to $53.5 \%$ in a period of $13.5 \mathrm{~min}$. This is a short time when compared to other drying techniques already used for dehydration of the acerola residue. The tray dryer requires 120 to $220 \mathrm{~min}^{[10]}$ and the fixed bed of $25 \mathrm{~cm}$ of thickness requires 159.3 to $300.7 \mathrm{~min}{ }^{[11]}$. The reduced time required for drying in a roto-aerated dryer is due to its excellent fluid-particle contact ${ }^{[3]}$. It is also worth mentioning that prolonged drying times can result in the degradation of bioactive compounds ${ }^{[2]}$.

The last two experiments (E18 and E19) were performed at the same operating conditions $\left(180.0{ }^{\circ} \mathrm{C}, 2.3 \mathrm{~m} / \mathrm{s}\right.$ and $\left.1188.3 \mathrm{~W}\right)$. However, the experiment E19 was performed with pretreatment with ethanol. The moisture reduction after the infrared was $22.9 \%$ and $34.0 \%$ and after the roto-aerated was of $59.1 \%$ and $91.1 \%$, for the acerola residue with (E19) and without ethanol pre-treatment (E18), respectively. 
Considering that a drying process can affect the final quality of the product, it is also important to evaluate the quality indices. The quality of acerola residues has been evaluated by the quantification of total phenolic compounds (TPC), total flavonoids (TFC) and antioxidant activity $\left(\mathrm{IC}_{50}\right)$.

Figure 2-b shows that TPC was lower in the conditions with higher power of the infrared lamps and/or higher drying air temperature. Phenolic losses may occur due to enzymatic and non-enzymatic oxidative reactions. Similar results were found by Nunes et al. ${ }^{[12]}$ in guava drying. According to Maillard and Berset ${ }^{[13]}$, thermal degradation also may contribute to phenolic losses. The highest reductions were $21.0 \%(522.0 \pm 20.0 \mathrm{mg} / 100 \mathrm{~g}$ d.w.) and 23.6\% (504.7 $\pm 21.0 \mathrm{mg} / 100 \mathrm{~g}$ d.w.) for conditions E14 (moisture $36.6 \mathrm{~g} / 100 \mathrm{~g}$ w.b.) and E18 (24.9 g/100 g d.w.), respectively. Despite the reductions in TPC, the dried material presents good potential and can be considered as with intermediate concentrations according to Vasco's classification ${ }^{[14]}$.

Fig. 2-c shows that the TFC of the acerola residues after drying, in all operating conditions, have been in higher levels. The highest levels of TFC were obtained in intermediate levels of infrared power and drying air velocity (E9 and E10). This behavior might be explained by the liberation of phenolic compounds due to the breaking of the cellular constituents during the drying process and due to presence of melanoidins and from the Maillard reaction, thereby interfering with the antioxidant properties ${ }^{[12]}$.

The antioxidant activity was evaluated using the $\mathrm{DPPH}^{*}$ radical capture method, the results were expressed as $\mathrm{IC}_{50}$ ( $\mu \mathrm{g}$ sample $/ \mathrm{mL}$ capable of reacting with $50 \%$ of the radical present in the $\mathrm{DPPH} *$ solution). Thus, the lower the $\mathrm{IC}_{50}$ value, the higher the antioxidant activity of the analyzed material. The lowest $\mathrm{IC}_{50}$ values were found in conditions E6, E7, E8, E10, E14 and E18, which had high drying air temperature and/or high infrared power, as can be seen in Figure 2-d. These were experimental conditions with greater moisture removal. However, even under these conditions the antioxidant activity was high. The heating of the material may increase the free flavonoid content and consequently the antioxidant capacity, which may change due to several factors such as the increase of the antioxidant power of the polyphenols in an intermediate state of oxidation, the increase of the reduction of sugars and the formation of products from Mailard reaction ${ }^{[1]}$.

Phenolic acids were determined in HPLC by comparison with the retention time of standards. Four phenolic acids were detected in the HPLC analyzes: gallic (165.3-280.1 $\mathrm{mg} / 100 \mathrm{~g}$ d.w.), caffeic (4.12-18.3 mg/100 g d.w.), chlorogenic (0.6-3.5 mg/100 g d.w.) and p-coumaric (2.6-13.2 mg/100 g d.w.) acids. The gallic acid content presented a reduction in relation to the fresh residue $(261.0 \pm 13.6 \mathrm{mg} / 100 \mathrm{~g} \mathrm{~d} . \mathrm{w}$.), this reduction was greater for the conditions with higher drying air temperature and infrared power. Similar behaviors were found for caffeic $(16.9 \pm 1.2 \mathrm{mg} / 100 \mathrm{~g} \mathrm{d.w}$.$) and chlorogenic (7.2 \pm 0.5 \mathrm{mg} / 100 \mathrm{~g}$ 
d.w.) acids. During drying processes, the activation of oxidative enzymes, such as polyphenoloxidase and peroxidase, in addition to the thermal degradation can lead to the loss of phenolic compounds ${ }^{[15]}$. Drying also dissociates some phenolic compounds, thereby altering chemical structures, transforming insoluble phenolic compounds into more soluble forms and making phenolic compounds more available for quantification, besides the formation of new compounds with antioxidant properties ${ }^{[15]}$.

\section{Conclusions}

The results showed that the new dryer system developed by our research group is a good alternative for drying of acerola wastes. It was possible to identify conditions with high moisture removal and short residence times that are suitable conditions to perform an efficient drying process with a preservation of product quality. It was possible to identify conditions under which the phenolic, flavonoid, and antioxidant capacity presented high levels after drying. The main phenolic compounds were idenfied by HPLC.

\section{Acknowledgements}

The authors are thankful for the financial support agencies CAPES, CNPq and FAPEMIG.

\section{References}

[1] Duzzioni, A.G., Lenton, V.M., Silva, D.I.S. \& Barrozo, M.A.S. (2013). Effect of drying kinetics on main bioactive compounds and antioxidant activity of acerola (Malpighia emarginata D.C.) residue. International Journal of Food Science \& Technology, 48, 1041-1047.

[2] Arenas, K. S. L.; Victoria, M. T. C. Y.; Vizcarra, M. G.; Vera, C. M.; Sosa, I. A. Effect of agitaded bed drying on the retention of phenolic compounds, anthocyanins and antioxidante activity of roselle (Hibiscus sabdariffa L.). International Journal of Food Science \& Technology, v. 51, p. 1457-1464, 2016.

[3] Silverio, B.C., Arruda, E.B., Duarte, C.R. \& Barrozo, M.A.S. (2015). A novel rotary dryer for drying fertilizer: Comparison of performance with conventional configurations. Powder Technology, 270, 135-140.

[4] Braga, A.M.P.; Silva, M.A.; Pedroso, M.P.; Augusto, F.; Barata, L.E.S. Volatile composition changes of pineapple during drying in modified and controlled atmosphere. International Journal of Food Engineering, v.6, p.1556-3758, 2010.

[5] AOAC. (1995). Official methods of analysis. Association of official analytical chemists, Gaithersburg.

[6] Singleton, V.L. \& Rossi, J.A. (1965). Colorimetry of total phenolics with phosphomolibidic_phosphotungistic acid reagents. The American Journal of Enology 
and Viticulture, 16, 144-158.

[7] Zhishen, J., Mengcheng, T. \& Jianming,W. (1999). The determination of flavonoid contents in mulberry and their scavenging effects on superoxide radicals. Food Chemistry, 64, 555-559.

[8] Brand-Wiliams, W., Cuvelier, M.E., Berset, C. Use of a free radical method to evaluate antioxidant activity. Food Science and Technology, v. 28, p.25-30, 1995.

[9] Ribeiro, L. F.; Ribani, R. H.; Francisco, T. M. G.; Soares, A. A.; Pontarolo, R., Haminiuk, C. W. I. Profile of bioactive compounds from grape pomace (Vitis vinifera and Vitis labrusca) by spectrophotometric, chromatographic and spectral analyses. Journal of Chromatography B, v. 1007, p. 72-80, 2015.

[10] Nóbrega, E. M. M. A. (2012) Secagem de resíduo de acerola (Malphigia emarginata DC.): estudo do processo e avaliação do impacto sobre o produto final. Master's thesis. Federal University of Rio Grande do Norte, Brazil, 102 p..

[11] Silva, D. I. S. (2015). Study of heat and mass transfer in fixed bed drying targeting the use of acerola residue (Malpighia emarginata DC). PhD Thesis, Federal University of Uberlândia, Brazil, 252 p.

[12] Nunes, J. C.; Lago, M. G.; Castelo-Branco, V. N.; Oliveira, F. R.; Torres, A. G.; Perrone, D.; Monteiro, M. Effect of drying method on volatile compounds, phenolic profile and antioxidant capacity of guava powders. Food Chemistry, v. 197, p.881$890,2016$.

[13] Maillard, M. N.; Berset, C. Evolution of antioxidant activity during kilning: Role of insoluble bound phenolic acids of barley and malt. Journal of Agricultural and Food Chemistry, Vol. 43, n. 7, p. 1789-1793, 1995.

[14] Vasco, C.; Ruales, J.; Kamal-Eldin, A. Total phenolic compounds and antioxidant capacities of major fruits from Ecuador. Food Chemistry, v. 111, n. 4, p. 816-823, 2008.

[15] Tomaino, A.; Cimino, F.; Zimbalatti, V.; Venuti, V.; Sulfaro, V.; De Pasquale, A.; Saija, A. Influence of heating on antioxidant activity and the chemical composition of some spice essential oils. Food Chemistry, v. 89, p. 549-554, 2005. 